\title{
Behaviour of compacted silt used to construct flood embankment
}

1 Gráinne El Mountassir MEng Research Fellow, Department of Civil Engineering, University of Strathclyde, Glasgow, UK

2 Marcelo Sánchez PhD

Associate Professor, Zachry Department of Civil Engineering, Texas A\&M University, Texas, USA
3 Enrique Romero $\mathrm{PhD}$

Director of Research, Departament d'Enginyeria del Terreny, Cartogràfica i Geofísica, Universitat Politècnica de Catalunya Barcelona, Spain

4 Ria A A Soemitro PhD

Lecturer, Civil Engineering Department, Institut Teknologi Sepuluh Nopember, Surabaya, Indonesia
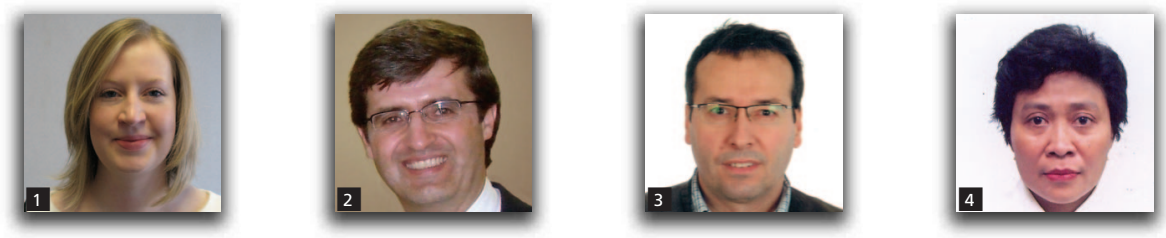

This paper investigates the unsaturated mechanical behaviour of a fill material sampled from flood embankments located along the Bengawan Solo River in Indonesia. In order to gain a better understanding of this fill material, in situ tests were carried out alongside an extensive laboratory programme. Two different phenomena related to changes in moisture content of the embankment fill material are experimentally studied herein: (a) volumetric collapse and (b) variation in shear strength with suction. At low densities, similar to those found in situ, the material exhibited significant volumetric collapse behaviour. Triaxial tests carried out under saturated, suction-controlled and constant water content conditions indicate that the shear strength of the material increased with suction; in particular the effective angle of friction increased from $24.9^{\circ}$ under saturated conditions to $35.8^{\circ}$ under air-dried conditions.

\section{Introduction}

Interest in the performance of flood embankments has increased in recent years in response to (a) catastrophic failure events and (b) climate change predictions. In particular, the failure of flood defences in New Orleans during hurricanes Katrina and Rita in 2005 contributed to the total loss of life of over 1800 people, and economic damage greater than $\$ 200$ billion was attributed to the storm event (Basham et al., 2009). This experience highlighted the important role of flood embankments in providing public safety during storm events. In the UK, the widespread flooding in the summer of 2007 resulted in damage estimated at $£ 3 \cdot 1$ billion (Defra, 2008). As a direct result of the impact of these flood events, investment in managing the risks of coastal and river flooding was increased to $£ 2 \cdot 15$ billion for the period 2008-2011 (Defra, 2008).

With regard to natural riverbanks, it is well known that changes in moisture content and suction due to changes in river level, infiltration and evapotranspiration affect both the shear strength of soils and seepage through riverbanks (Nam et al., 2009). Increasingly, studies have shown that the consideration of unsaturated soil behaviour is key to understanding the erosion and instability of natural riverbanks (e.g. Dapporto et al., 2001, 2003; Nam et al., 2009; Rinaldi et al., 2004). It is proposed here that the unsaturated behaviour of soils present in earth flood embankments should similarly be considered when analysing structural performance, particularly as such structures are typically constructed from compacted fill (often dry of optimum), and during post-construction they are subjected to similar changes in moisture content as natural riverbanks.

This paper investigates fill material sampled from flood embankments located along the Bengawan Solo River in East Java, Indonesia. The novel experimental information reported in this paper contributes to the relatively small body of experimental data available in the literature related to the unsaturated behaviour of compacted fills used for flood embankments. The paper is organised as follows: issues associated with constructing flood protection embankments in tropical regions are discussed first; then a brief description of the Bengawan Solo site is presented, alongside a discussion of past failures observed at the site. The specific objectives of the experimental programme presented in this paper are: (a) to characterise the Bengawan Solo fill material using both in situ and laboratory data; and (b) to 
investigate the mechanical behaviour of this fill material under different saturation conditions using information obtained in conventional oedometer tests, and in conventional and suctioncontrolled triaxial tests. Two different phenomena related to changes in moisture content of the embankment fill material are experimentally studied herein: (a) volumetric collapse and (b) variation in shear strength with suction. To explore the influence of saturation on embankment stability, a slope stability analysis has been performed using soil properties determined in the experimental programme.

\section{Flood embankments}

\subsection{Construction issues}

Many flood embankments in the UK are relatively old structures that have been upgraded over decades or even centuries from original constructions (Morris et al., 2007). In contrast with embankments associated with highway and dam projects, flood embankments have often been constructed using traditional lowcost techniques rather than modern construction methods (Morris et al., 2007). The type of traditional method used generally depends on the local sources of fill material available (Morris et al., 2007), and these less rigorous methods can subsequently result in poorly controlled compaction during construction.

Additional challenges are faced when constructing flood embankments in tropical regions. Perhaps the greatest of these is the extreme weather experienced in such regions, typified by the dry and wet monsoon seasons. Such climatic conditions mean that the embankments must be able to withstand high hydraulic gradients due to rapidly rising water levels during storm events. Another consequence is that construction of the embankments can be carried out only during the dry season, when river levels are low (Brown, 1999). In areas where population density is high, settlements can restrict realignment or relocation of embankments during upgrades (Brown, 1999). The lack of available land in densely populated urban areas or poor access routes in remote rural areas can prevent large construction equipment from reaching sites, resulting in smaller items of plant often being used (Brown, 1999). The issue of securing suitable local material is perhaps of greater importance in tropical regions, where it is simply not economically feasible to transport material, even for short distances (Brown, 1999). Further limitations associated with construction costs can result in the use of an unskilled local workforce. However, projects do benefit from local knowledge regarding site-specific flood issues, and, if properly conducted, knowledge transfer can ensure continued maintenance of defences by local communities (FAO RAP, 1999). The difficulties associated with obtaining good-quality fill material, available funds and poor access to site can all lead to traditional, less rigorous construction methods being used. Brown (1999) experienced many of the difficulties listed above during construction of flood embankments along the Mekong River, Thailand.

\subsection{Failure mechanisms}

The main, widely accepted failure mechanisms occurring in flood embankments are listed in Table 1. References related to research regarding each failure mechanism are provided where possible, but this is not intended to be an exhaustive list. In general, most of the mechanisms related to founding layers are investigated by assuming saturated conditions. The mechanisms related to the fill material, on the other hand, may occur at varying degrees of saturation. Some of the different mechanisms related to the erosion of flood embankments may occur under unsaturated conditions, for example erosion of the outward face due to wave attack, erosion of the crest and slope faces due to rainfall, and erosion of the landward face due to overtopping. In these cases the variation in shear strength with soil suction may significantly influence the resistance of the fill material to erosion (Nam et al., 2009). Fissuring of clay embankments due to soil-environment interactions has commonly been reported, where drying of the soil induces cracks, which may extend within the embankment (Dyer et al., 2009), and has been linked with shallow slip failures of the landward face (Cooling and Marsland, 1954). Rapid drawdown failure (embankment instability caused by rapidly lowering river levels) is classically investigated considering an undrained approach for low-permeability materials, but recently efforts have been made to analyse such mechanisms using fully coupled flow-deformation analyses (Pinyol et al., 2008).

From the description above, it is evident that the response of fill material may be affected significantly by changes in moisture content and suction. However, despite this, few experimental programmes investigating the unsaturated mechanical behaviour of fill material from flood embankments are available in the literature (e.g. Hoffmann and Tarantino, 2008), and fewer still have been carried out under suction-controlled conditions. In this paper the mechanical behaviour of the Bengawan Solo fill material is investigated under saturated, suction-controlled and constant water content conditions. A classical stability analysis using information obtained in the experimental programme is discussed in Section 6 to explore the influence of this phenomenon on embankment failure. A short description of the Bengawan Solo site and the geotechnical failures observed along the embankments is presented in the next section.

\section{Bengawan Solo site}

The soil investigated here was sampled from a site located along the flood defence embankments of the Bengawan Solo River, in the village of Kedungharjo, East Java, Indonesia. The Bengawan Solo River is the longest river on the Island of Java, at approximately $600 \mathrm{~km}$ long. The source is located in central Java, and the river enters the sea north of Surabaya in East Java (see Figure 1). The embankments along the Bengawan Solo River have a history of overtopping and failure (Hidayat et al., 2008; Jakarta Post, 2009). The very high population density in the river basin (810 people $/ \mathrm{km}^{2}$; Hidayat et al., 2008), means that villages are often located directly behind the flood embankments, and hence flooding can result in the relocation of entire villages, and 
Failure mechanisms occurring in References

flood embankments

\begin{tabular}{|c|c|c|}
\hline \multirow[t]{5}{*}{$\begin{array}{l}\text { Founding } \\
\text { layers }\end{array}$} & $\begin{array}{l}\text { Deep-seated slope instability } \\
\text { due to soft clay founding layers }\end{array}$ & Dyer (2004); Leroueil et al. (1990) \\
\hline & $\begin{array}{l}\text { Excessive uplift pressures in } \\
\text { underlying layers }\end{array}$ & $\begin{array}{l}\text { Baudin et al. (1989); Cooling and Marsland (1954); Dyer (2004); Hird et al. } \\
\text { (1978); Marsland (1957); Marsland and Randolph (1978); Padfield and Schofield } \\
\text { (1983) }\end{array}$ \\
\hline & $\begin{array}{l}\text { Translational sliding due to } \\
\text { organic founding layers }\end{array}$ & $\begin{array}{l}\text { Bezuijen et al. (2005); Dyer (2004); Van et al. (2005); Ward (1948); Ward et al. } \\
\text { (1955) }\end{array}$ \\
\hline & Internal erosion (e.g. piping) & Dunbar et al. (1999); Morris et al. (2007); Perry (1998) \\
\hline & $\begin{array}{l}\text { Settlements due to consolidation } \\
\text { or creep }\end{array}$ & $\begin{array}{l}\text { Cooling and Marsland (1954); Leroueil et al. (1990); Lindenberg and de Groot } \\
\text { (1998) }\end{array}$ \\
\hline \multirow[t]{8}{*}{$\begin{array}{l}\text { Fill } \\
\text { material }\end{array}$} & $\begin{array}{l}\text { Erosion of outward face due to } \\
\text { river current or wave attack }\end{array}$ & $\begin{array}{l}\text { Cooling and Marsland (1954); Dunbar et al. (1999); Dyer (2004); Lindenberg ano } \\
\text { de Groot (1998); Marsland (1957); Perry (1998) }\end{array}$ \\
\hline & $\begin{array}{l}\text { Erosion of landward face due to } \\
\text { overtopping }\end{array}$ & $\begin{array}{l}\text { Cooling and Marsland (1954); Dyer (2004); Marsland (1957); Miller and Ralston } \\
\text { (1987); Möller et al. (2002); Perry (1998) }\end{array}$ \\
\hline & $\begin{array}{l}\text { Rainfall erosion of slopes and } \\
\text { crest }\end{array}$ & Perry (1998) \\
\hline & $\begin{array}{l}\text { Internal erosion (e.g. piping, } \\
\text { suffosion) }\end{array}$ & $\begin{array}{l}\text { Dunbar et al. (1999); Ghataora et al. (2007); Lindenberg and de Groot (1998); } \\
\text { Morris et al. (2007); Perry (1998) }\end{array}$ \\
\hline & $\begin{array}{l}\text { Shallow slippage of outward } \\
\text { face due to erosion }\end{array}$ & Dyer (2004); Simon et al. (2003) \\
\hline & $\begin{array}{l}\text { Shallow slippage of landward } \\
\text { face due to through-seepage }\end{array}$ & $\begin{array}{l}\text { Cooling and Marsland (1954); Dyer et al. (2009); Marsland (1957, 1968); Perry } \\
\text { (1998); Sentenac and Zielinski (2009) }\end{array}$ \\
\hline & Flow slides due to liquefaction & Dunbar et al. (1999); Lindenberg and de Groot (1998) \\
\hline & Rapid drawdown & Pinyol et al. (2008); Rinaldi et al. (2004); Simon et al. (2002) \\
\hline
\end{tabular}

Table 1. Failure mechanisms occurring in flood embankments

even fatalities. Floods in late December 2007 and early January 2008 resulted in the deaths of over 100 people and the evacuation of 200000 people from their homes (Hidayat et al., 2008). Total economic damage associated with infrastructure during these floods is estimated at 2000 billion Indonesian rupiahs, approximately $£ 145$ million (Hidayat et al., 2008).

Figure 2a presents a cross-section of the Bengawan Solo River and embankments at the village of Kedungharjo. At this site the Bengawan Solo River is $100 \mathrm{~m}$ wide and the river level may vary by as much as $10 \mathrm{~m}$ between the dry and wet seasons (Figure 2a). Takeuchi et al. (1995) present hydrological data recorded at the Bojonegoro observation station, located at a distance of approximately $40 \mathrm{~km}$ from the site (see Figure 1). Although temperatures in the area remain fairly constant throughout the year, ranging from $26^{\circ} \mathrm{C}$ to $28^{\circ} \mathrm{C}$, evaporation greatly exceeds precipitation for six months of the year (May to October). During the dry season, the lowered river level and higher levels of evaporation both contribute to reduce the moisture content of the fill material within the embankment body.

The Bengawan Solo River is bounded on one side by a natural embankment (Figure 2), the existing riverbank, which is in a continual state of extensive erosion (Figure 2b). On the other side of the river, a man-made embankment protects the village of Kedungharjo from flooding. A section of this embankment was upgraded during the dry season of 2005 to include gabion reinforcement of the outward face to protect against erosion (Figure 2d). In order to carry out this upgrade, sediment was removed from the riverbed and spread on top of the existing embankment to dry. This material was subsequently compacted in layers of $40 \mathrm{~cm}$ using light compaction plant to a dry density $80-$ $85 \%$ of the standard Proctor optimum, on the dry side of optimum (Soemitro, private communication, 2006). Global failure of the gabion-reinforced section of embankment (see Figure 3) occurred in December 2005, during the first wet season after its construction (Soemitro, private communication, 2006).

During exploration of the site, extensive erosion and widespread desiccation of embankment faces were observed along the natural and man-made embankments of the Bengawan Solo River (El Mountassir, 2011). Although not investigated further in this paper, cracking of the Bengawan Solo fill material due to drying is currently being studied as part of another research project at the University of Strathclyde (Atique et al., 2009). Further downstream, rapid drawdown failures have also occurred in the 


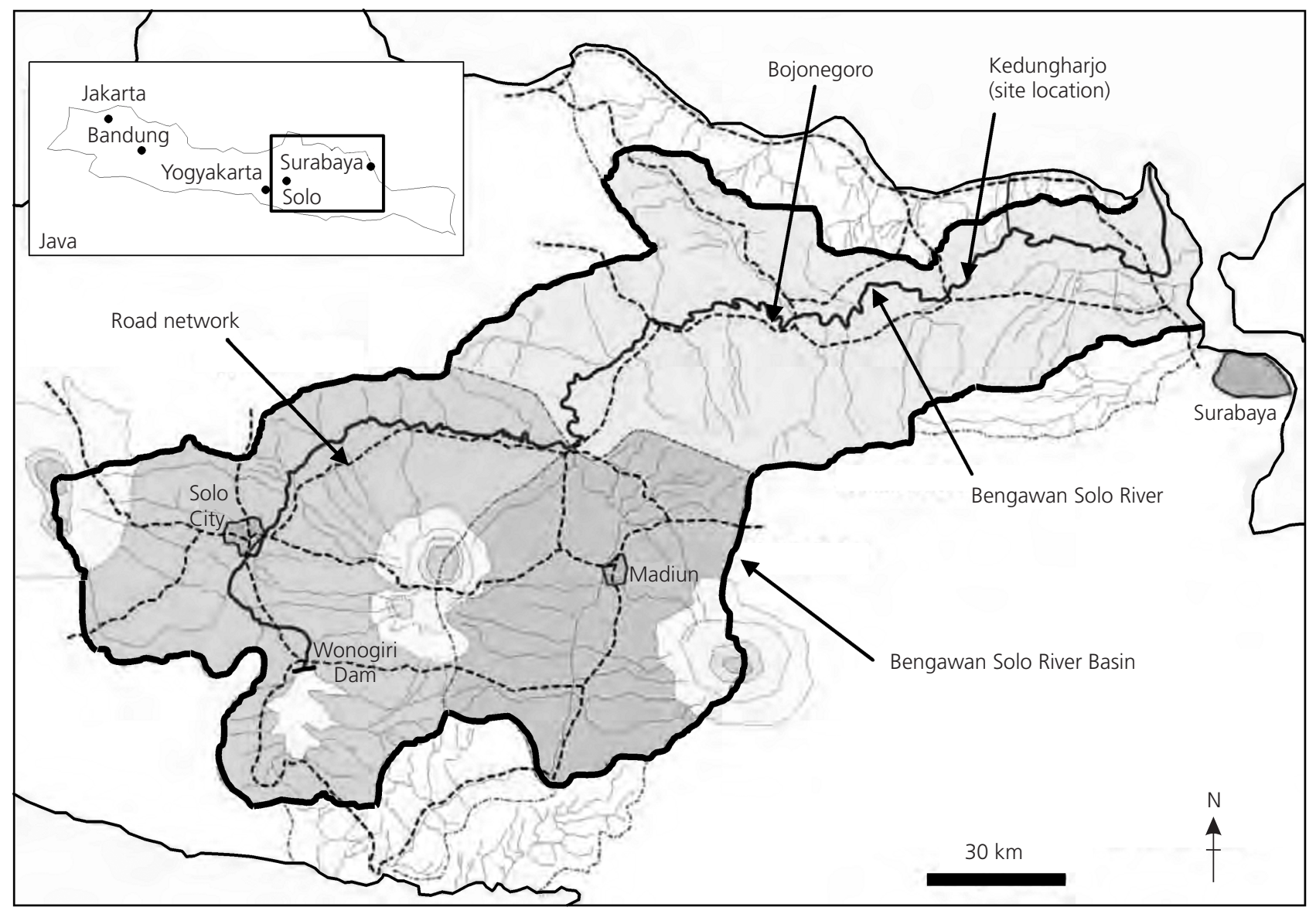

Figure 1. Map of Bengawan Solo River and catchment area in East Java, Indonesia. Site located in Kedungharjo (Adapted from Sudarsono, 2009)

Bengawan Solo embankments as a result of closure of the Babat barrage (Soemitro, private communication, 2006).

\section{Soil characterisation}

This section presents the in situ and laboratory tests performed to characterise the Bengawan solo soil, including information on the compaction and water retention behaviour of this compacted fill.

\subsection{Site investigation}

The geology of the Bengawan Solo River Basin is presented in Figure 4, which indicates that the site is predominantly characterised by alluvium deposits. Information on the soils present within and below the man-made and natural embankments at the Kedungharjo site is summarised in Figure 5. These data were obtained from two boreholes (locations marked in Figure 2) drilled by Institut Teknologi Sepuluh Nopember (ITS) in September and October 2005 (Soemitro, 2005). The borehole data for both embankments indicate subsurface layers of varying fractions of sand, silt and clay (typical of alluvial soils). Below the manmade embankment (Figure 5a) $N$ values are within the range 6-8 blows per $30 \mathrm{~cm}$ of soil penetration. The founding soils below the natural embankment (Figure 5b), on the other hand, show greater variation, ranging from 2 to 23 blows required per $30 \mathrm{~cm}$ penetration. Assuming a correlation between undrained shear strength $\left(C_{\mathrm{u}}\right)$ and SPT $N$ values of $C_{\mathrm{u}}=5 N$ (Stroud and Butler, 1975) and according to BS 8004 (BSI, 1986) the founding material below the man-made embankment is mainly soft soil (Figure 5a), whereas below the natural embankment (Figure 5b) the material ranges from very soft to stiff.

In situ dry densities of the fill material were determined using the sand replacement method in accordance with BS1377-9 (BSI, 1990a). Low dry densities, ranging from 1.18 to $1.36 \mathrm{Mg} / \mathrm{m}^{3}$, were recorded. From the soil excavated during the sand replacement testing method, samples were retrieved, sealed in airtight containers, and taken back to the laboratory for moisture content determination. High moisture contents ranging from $36 \%$ to $43 \%$ were determined, which reflected the fact that the site investigation was carried out at the end of the wet season (in early May 2006), and one week prior to the visit the embankments had been overtopped. Shear vane tests were carried out to determine the undrained shear strength of the embankment fill according to BS 


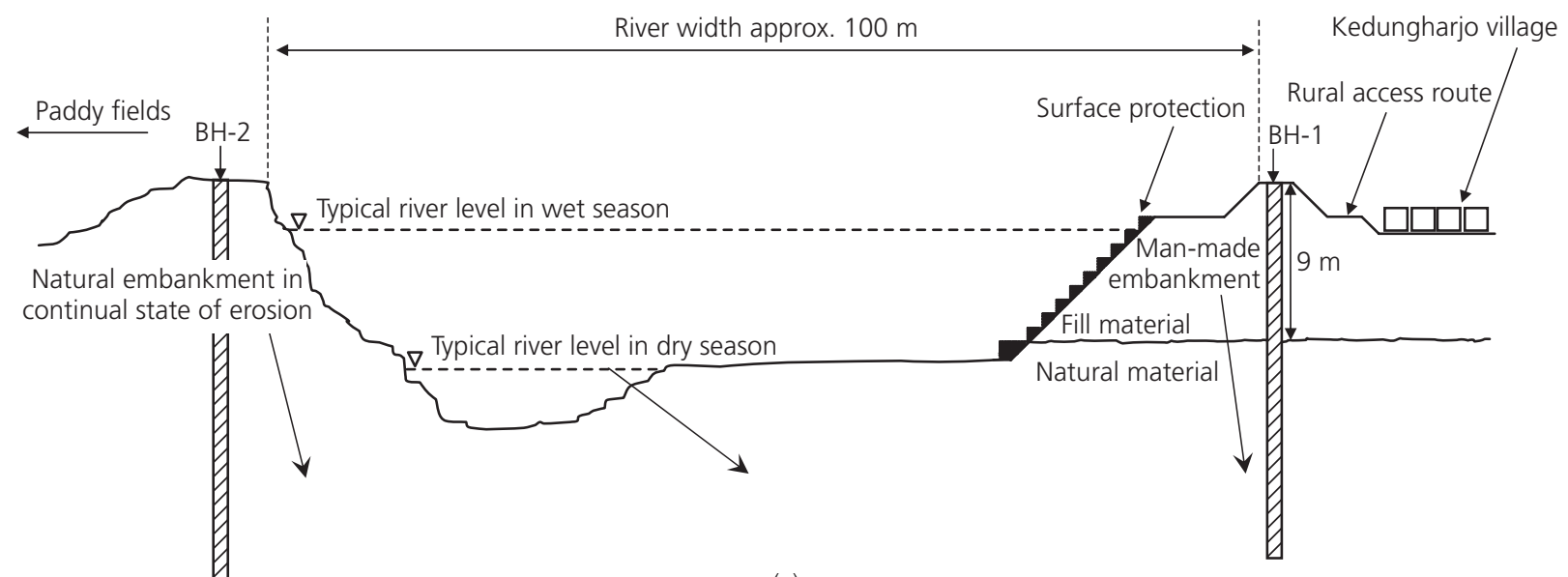

(a)

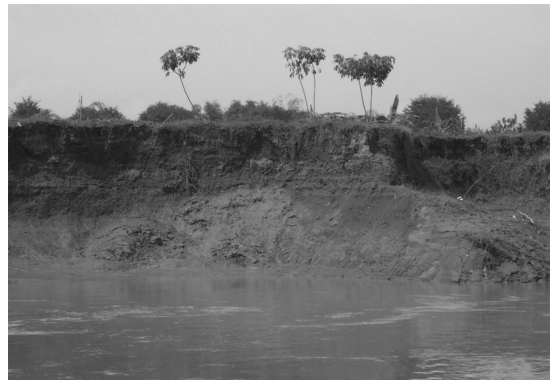

(b)

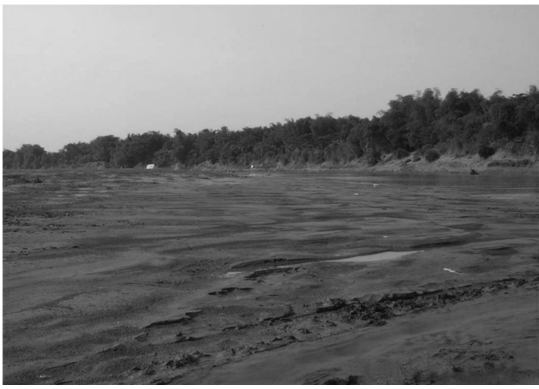

(c)

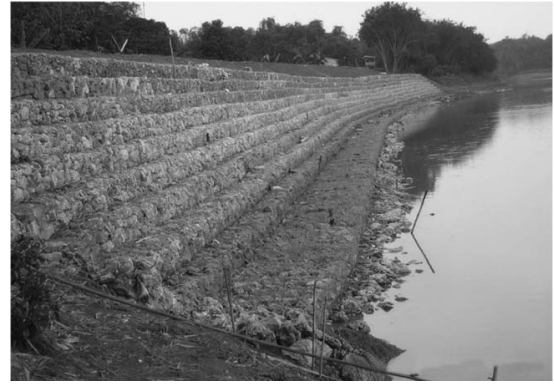

(d)

Figure 2. Bengawan Solo River and embankments at

Kedungharjo village: (a) river cross-section (not drawn to scale); (b) extensive erosion of natural embankments; (c) low river level during dry season; (d) gabion-reinforced section of embankment to protect against erosion of embankment face

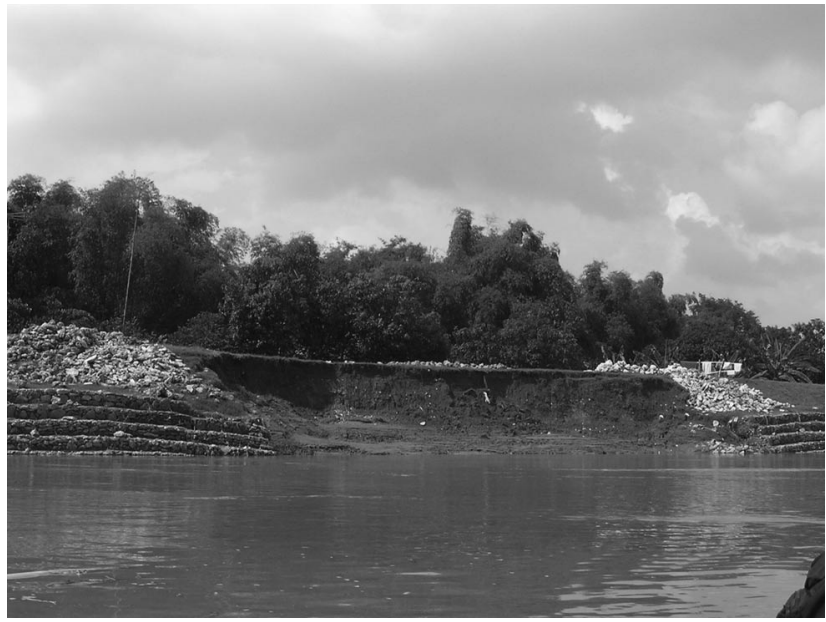

Figure 3. Global failure of gabion-reinforced section of embankment, which occurred during the first wet season after construction
1377-9 (BSI, 1990a). Undrained shear strength ranged from 20 to $40 \mathrm{kPa}$, indicating that the fill material is a soft soil as defined in BS 8004 (BSI, 1986).

The tests presented in this paper were all carried out on disturbed material that was sampled from the embankment at depths of $0.5-1.0 \mathrm{~m}$ and $1.0-1.5 \mathrm{~m}$, and remoulded and compacted in the laboratory. Considering that the embankment fill is all material that has been retrieved from the river bed, and is essentially local alluvial deposits that have been eroded into the river, it is assumed herein that the material sampled at shallow depths is representative of the fill material found within the embankment body.

\subsection{Soil properties}

Table 2 presents the basic soil properties of the Bengawan Solo fill for depths of $0.5-1.0 \mathrm{~m}$ and $1.0-1.5 \mathrm{~m}$. The fill material plots below the A-line of Casagrande's plasticity chart, indicating that it is a silt. According to BS 5930 (BSI, 1999), it can be classified as an organic silt of high plasticity (MHO). The 


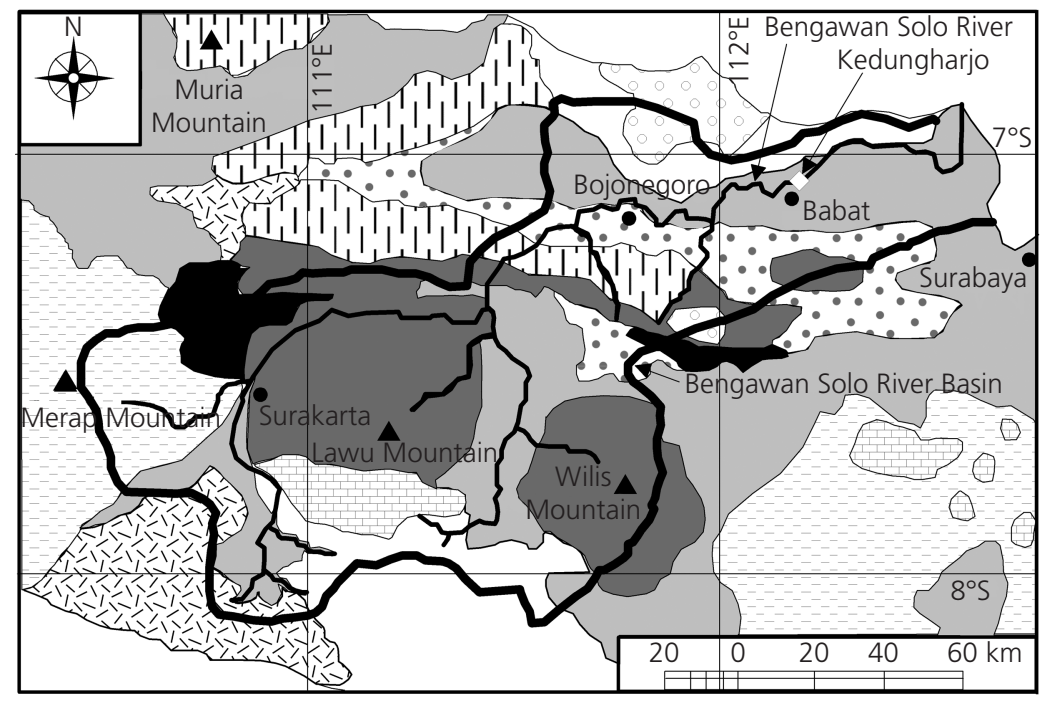

Legend

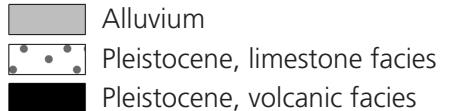

ए। Pliocene, sedimentary facies

Pliocene, limestone facies

Miocene, sedimentary facies

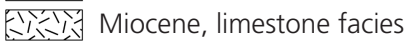

Undifferentiated volcanic products

Young Quarternary volcanic products

Old Quarternary volcanic products

Figure 4. Geological map of Bengawan Solo River basin, East Java, Indonesia (after Takeuchi et al., 1995)

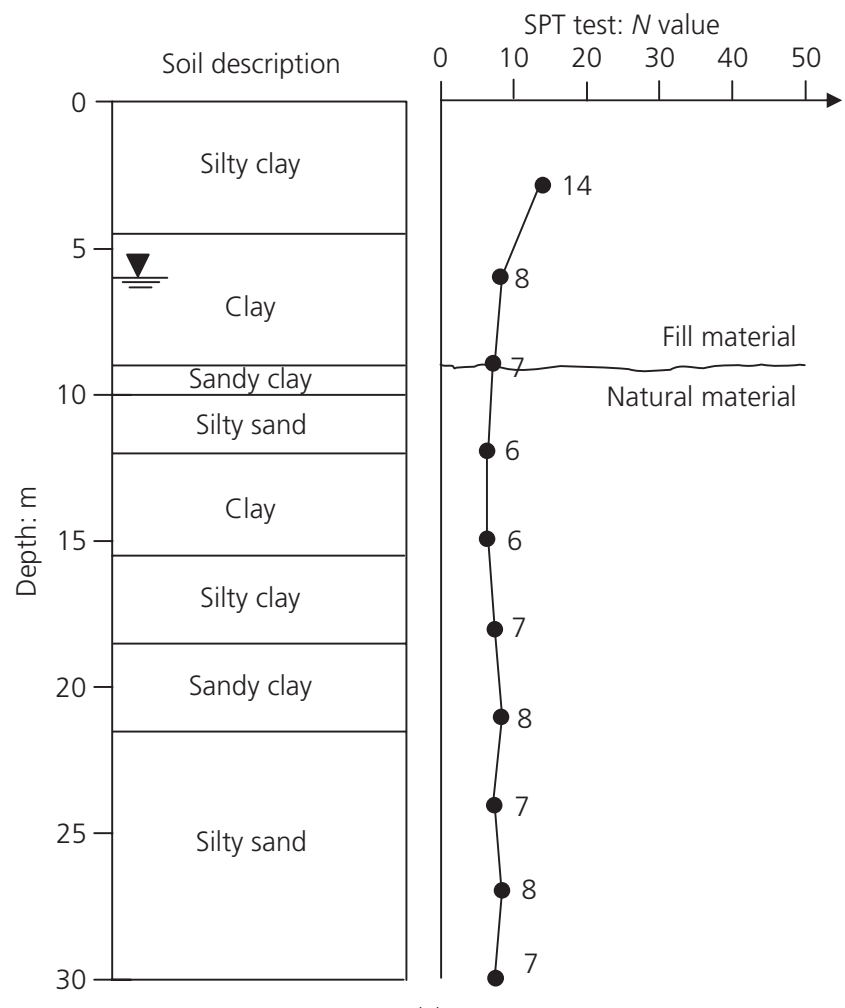

(a)

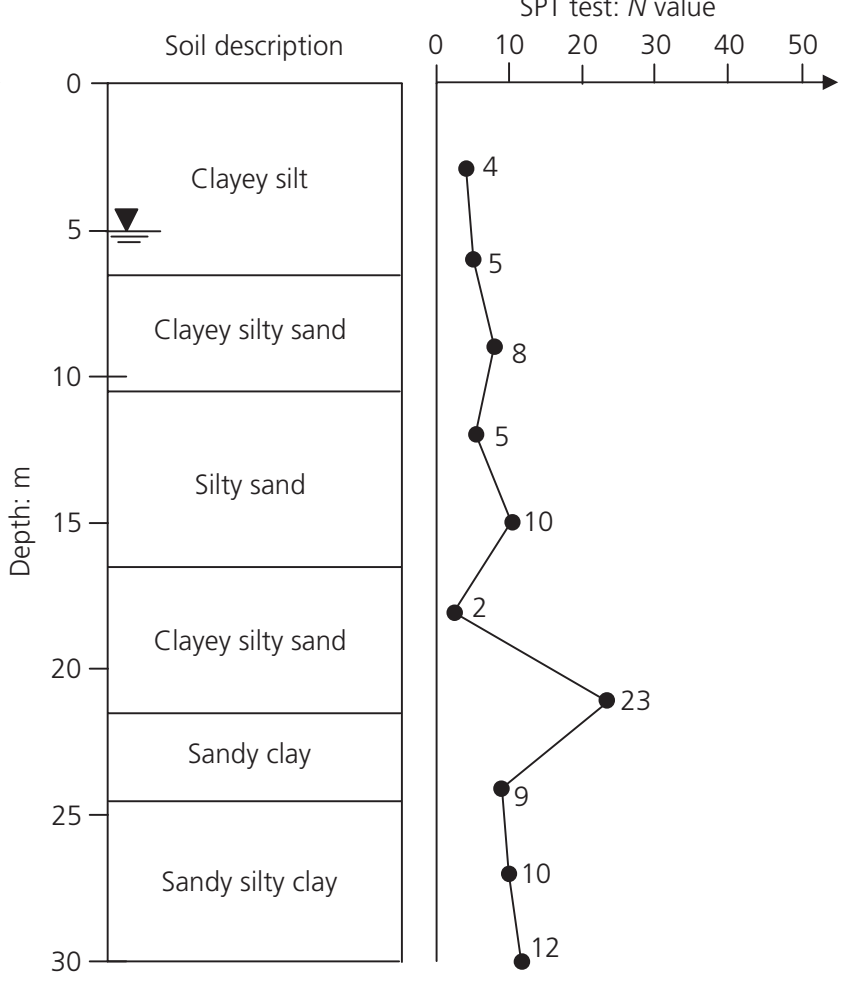

(b)

Figure 5. Soil profile up to a depth of $30 \mathrm{~m}$ at Kedungharjo:

(a) $\mathrm{BH}-1$, man-made embankment; (b) $\mathrm{BH}-2$, natural

embankment (borehole data after Soemitro, 2005)

Bengawan Solo fill has a particle density of $2.72 \mathrm{Mg} / \mathrm{m}^{3}$, and consists of a large silt fraction (55-57\%) with a significant sand content $(29-30 \%)$ and a smaller clay fraction $(13-16 \%)$. The soil mineralogy was investigated using X-ray diffraction, and smectite was found to be the dominant mineral present in the clay fraction (88\%). The presence of smectite explains the high activity determined for this fill material $(A \geqslant 1)$, despite the small clay fraction. 


\begin{tabular}{lcc}
\hline Property & D1: 0.5-1.0 m & D2: $1 \cdot 0-1 \cdot 5 \mathrm{~m}$ \\
\hline Particle density: Mg/m & $2 \cdot 73$ & $2 \cdot 72$ \\
Sand content: \% & 30 & 29 \\
Silt content: \% & 57 & 55 \\
Clay content: \% & 13 & 16 \\
Uniformity coefficient & 29 & 27 \\
Liquid limit: \% & 54 & 53 \\
Plastic limit: \% & 36 & 37 \\
Shrinkage limit: \% & 14 & 15 \\
Plasticity index: \% & 18 & 16 \\
Activity & $1 \cdot 4$ & 1 \\
Organic content: \% & 8 & 6 \\
BSCS classification & $\mathrm{MHO}$ & MHO
\end{tabular}

Table 2. Soil properties

\subsection{Compaction behaviour}

As the material was to be remoulded and compacted for laboratory tests, it was important to investigate the compaction behaviour of the Bengawan Solo fill material. Figure 6 presents the compaction characteristics of this fill material under two different compactive efforts. The British Standard heavy and light tests were carried out according to BS 1377-4 (BSI, 1990b), with input energies per unit volume of $2682 \mathrm{~kJ} / \mathrm{m}^{3}$ and $596 \mathrm{~kJ} / \mathrm{m}^{3}$ respectively.

A maximum dry density of $1.47 \mathrm{Mg} / \mathrm{m}^{3}$ at an optimum moisture content of $28 \%$ was determined for the BS light condition (same energy level as standard Proctor test). The man-made sections of

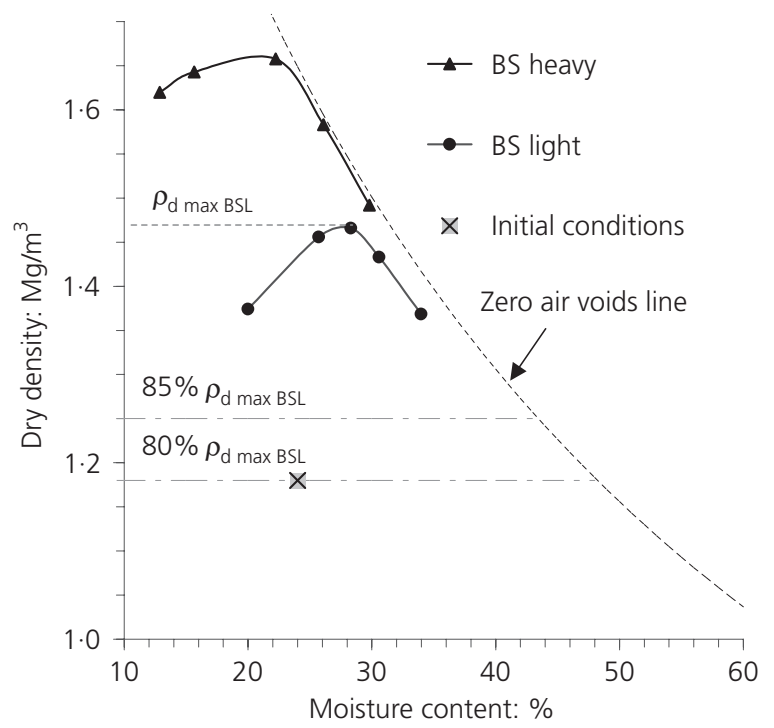

Figure 6. Compaction curves at two different energy levels: (a) BS light $\left(596 \mathrm{~kJ} / \mathrm{m}^{3}\right)$; (b) BS heavy $\left(2682 \mathrm{~kJ} / \mathrm{m}^{3}\right)$ embankments were constructed at $80-85 \%$ of the optimum standard Proctor dry density during the dry season, with fill material at moisture contents dry of optimum (Soemitro, private communication, 2006).

The specimens tested in the oedometer and triaxial tests were all prepared at an initial condition of $24 \%$ and $1 \cdot 18 \mathrm{Mg} / \mathrm{m}^{3}$. This condition (highlighted in Figure 6) was selected for investigation, as it is equivalent to $80 \%$ of the standard maximum dry density, and it was also the lowest in situ dry density determined. It was felt preferable to study specimens with an initial moisture content dry of optimum, in an attempt to represent the initial asconstructed conditions of the embankment.

\subsection{Soil water retention behaviour}

Soil water retention curves describe the relationship between water content and suction in unsaturated soils. Considering the significant moisture content changes likely to occur in flood embankments (changes in river level, rainfall and evaporation), soil water retention curves provide important information on corresponding changes in soil suction. Figure 7 presents the soil water retention behaviour of the Bengawan Solo fill following drying paths.

The filter paper method was used to determine matric suctions up to $1 \mathrm{MPa}$, following the detailed procedures given in Bulut et al. (2001), using Whatman No. 42 filter paper. Filter paper measurements were carried out on single specimens subjected to drying paths with initial moisture contents of $24 \%$ and $36 \%$ respectively, both compacted at an initial dry density of $1.18 \mathrm{Mg} / \mathrm{m}^{3}$. For the specimen compacted at a moisture content of $24 \%$, an initial

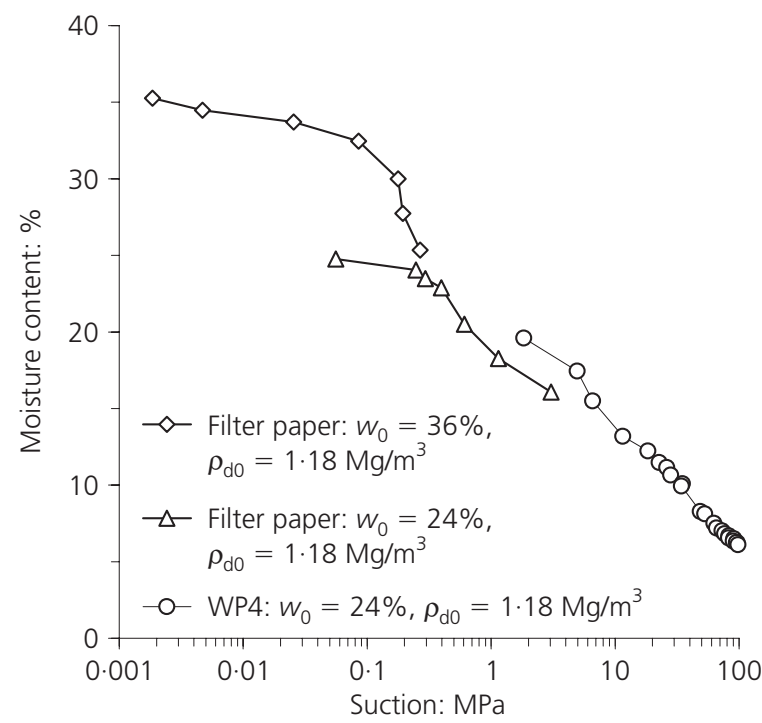

Figure 7. Soil water retention curves determined using the filter paper method (0.002-3 MPa), chilled mirror dew-point technique, WP4 (1-100 MPa) 
reduction in moisture content of less than $1 \%$ corresponds to an increase in suction of around $200 \mathrm{kPa}$, indicating that very small changes in moisture content can result in significant changes in suction. For the Bengawan Solo fill, it appears that drying causes the specimens to follow a scanning curve (pre-yield) before joining a main drying curve (post-yield); such scanning curves are discussed in Nuth and Laloui (2008). It is interesting to note that the specimen compacted at an initial lower water content exhibited a slightly stiffer pre-yield scanning response.

The chilled mirror dew-point pyschrometer was used to determine total suctions up to $100 \mathrm{MPa}$ using the WP4 potentiameter (Decagon Devices). Successive WP4 measurements were carried out on the same soil specimen following a drying path (initial $w=24 \%$, initial $\rho_{\mathrm{d}}=1 \cdot 18 \mathrm{Mg} / \mathrm{m}^{3}$ ). After continued drying in the laboratory, the specimen reached an almost constant moisture content of $6 \cdot 2 \%$, for which a maximum suction of $96.6 \mathrm{MPa}$ was determined. The WP4 data appear to be slightly shifted with respect to the filter paper measurements. Considering that the WP4 measurements correspond to total suction and the filter paper measurements to matric suction, this difference may be assumed to be equal to the osmotic potential of the Bengawan Solo fill material.

The soil water retention curves determined have been used to inform the unsaturated mechanical experimental programme presented in the next section. Furthermore, such information may be required for advanced finite-element modelling involving unsaturated soils, although such modelling is beyond the scope of this paper.

\section{Mechanical behaviour}

The mechanical behaviour of the Bengawan Solo fill was investigated under different saturation conditions in order to: (a) investigate the potential for volumetric collapse behaviour; and (b) investigate the influence of suction on shear strength behaviour.

\subsection{Volumetric collapse behaviour}

A load and soak test was carried out using conventional oedometer apparatus in order to investigate the potential for volumetric collapse in the Bengawan Solo fill material. Specimens were prepared at the same initial conditions of $w=24 \%$, $\rho_{\mathrm{d}}=1.18 \mathrm{Mg} / \mathrm{m}^{3}$, from air-dried material passing the $2 \mathrm{~mm}$ sieve. Specimens were compacted in retaining rings $(60 \mathrm{~mm}$ in diameter, $18 \mathrm{~mm}$ high) in three layers.

The saturated test was carried out by soaking the specimen under a contact load of $3 \mathrm{kPa}$. A small amount of swelling was recorded: see Figure 8 (swelling potential $=1 \cdot 8 \%$ ). No water was added to the constant water content test, and only pore air drainage was permitted through the top cap of the specimen. In the load and soak test, the specimen was initially loaded under constant water content conditions; water was then added at a vertical stress of $125 \mathrm{kPa}$. It is evident from Figure 8 that soaking resulted in significant settlement, corresponding to a collapse potential as defined by Jennings and Knight (1957) of $11 \cdot 6 \%$. Fookes (1990) suggested that collapse potentials between $10 \%$ and $20 \%$ were likely to be of significance in engineering problems, and rated these as 'severe trouble' problems.

It is important to note here that the engineering works implemented along the Bengawan Solo embankments to protect against erosion (i.e. the gabions illustrated in Figures 2 and 3) provide an additional loading to the fill material. It is proposed here that the collapsible nature of the Bengawan Solo fill material under low density, and dry of optimum compaction conditions, may play a role in triggering failure mechanisms in the embankments, particularly considering that additional loading has been introduced in the form of flood embankment protection. Further experimental investigation and numerical analysis are ongoing at the University of Strathclyde to assess whether the volumetric collapse mechanism played a role in triggering the global failure of the gabion reinforced embankment observed in Figure 3.

\subsection{Shear strength behaviour}

Of particular interest in this research was the variation in shear strength of the Bengawan Solo fill material with changes in suction. This was investigated by testing specimens at four different levels of suction:

(a) $s=0 \mathrm{kPa}$ (saturated conditions)

(b) $s=50 \mathrm{kPa}$ (suction controlled)

(c) $s=400 \mathrm{kPa}$ (suction controlled)

(d) $s \approx 100 \mathrm{MPa}$ (constant water content)

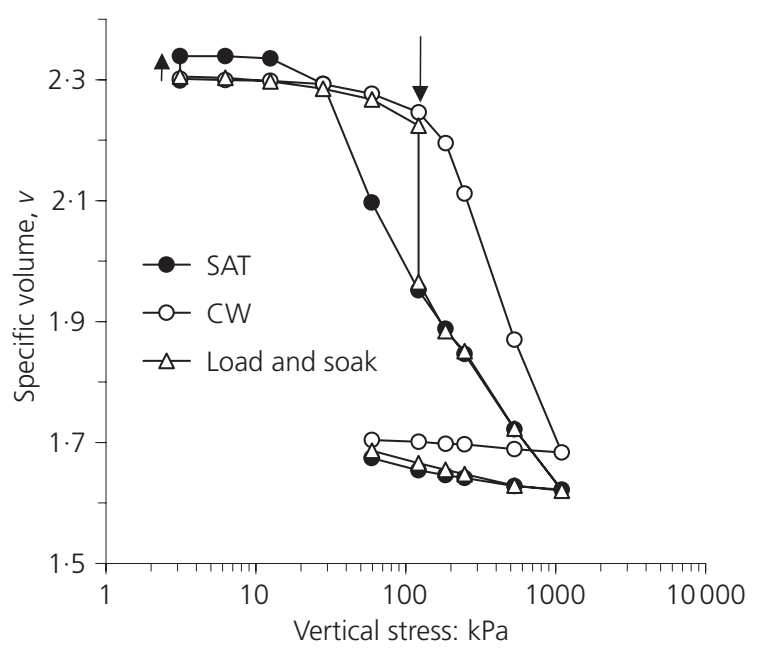

Figure 8. One-dimensional consolidation of specimen with initial water content and initial dry density of $24 \%$ and $1.18 \mathrm{Mg} / \mathrm{m}^{3}$ respectively, under saturated, constant water content and load and soak conditions 
where $s=u_{\mathrm{a}}-u_{\mathrm{w}}, u_{\mathrm{a}}=$ pore air pressure, and $u_{\mathrm{w}}=$ pore water pressure. Traditional triaxial apparatus was adapted for the study of unsaturated soils by incorporating the axis-translation technique (Hilf, 1956). This was achieved by the installation of a high-air-entry ceramic disc in the base pedestal. Pore air pressure was introduced to the specimen by way of the top cap. The traditional acrylic cell body was replaced by a stainless steel cell body. Two GDS Instruments pressure-volume controllers were used in the triaxial set-up: one to control the cell pressure, and the other to control the pore water pressure applied underneath the ceramic disc. A $5 \mathrm{kN}$ load cell, $25 \mathrm{~mm}$ linear variable differential transformer (LVDT) and $1700 \mathrm{kPa}$ pore water pressure transducer (for the saturated tests) were all connected to a PC using a GDS data acquisition pad. Further information on the experimental set-up used is presented in El Mountassir (2011).

Specimens $38 \mathrm{~mm}$ in diameter and $76 \mathrm{~mm}$ high were all prepared at similar initial conditions $\left(w=24 \%, \rho_{\mathrm{d}}=1.18 \mathrm{Mg} / \mathrm{m}^{3}\right)$ : see Table 3. Specimens were compacted dynamically in a three-part split mould in five layers of equal mass (total mass $=132.5 \mathrm{~g}$ ). For the saturated tests, specimens were wetted by circulating water from the base pedestal under an effective confining stress of $8 \mathrm{kPa}$, followed by ramping the cell pressure to $210 \mathrm{kPa}$ and the pore water pressure to $200 \mathrm{kPa}$. After these two saturation stages, $B$ values $>0.97$ were achieved. In the suction-controlled tests, specimens were brought to the desired suctions $(50 \mathrm{kPa}$ and $400 \mathrm{kPa}$ ) by controlling the pore air and pore water pressures. To minimise air diffusion through the ceramic stone, the pore water pressure was maintained at an elevated value, as recommended by Delage et al. (2008); a minimum of $200 \mathrm{kPa}$ was used in these tests. To study the behaviour of the fill material under much higher suctions, the specimens were air-dried in the laboratory for 5 days, until a constant water content was reached $(w \approx 6 \%)$. Referring back to the soil water retention curves presented in Figure 7, this corresponds to a suction of approximately $100 \mathrm{MPa}$. The air-dried specimens were investigated in order to obtain the shear strength data for the soil under maximum soil suction. After equalisation at the desired suction, specimens were loaded to net confining stresses of $25 \mathrm{kPa}$, $100 \mathrm{kPa}$ or $300 \mathrm{kPa}$, and then allowed to consolidate prior to shearing. These confining stresses were selected to represent the confining stresses found close to the crest of the embankment, at the base of the embankment, and within the founding layers respectively. Shearing was carried out at a rate of $0.005 \mathrm{~mm} / \mathrm{min}$. During shearing, pore water drainage was allowed in the saturated tests. Pore air and pore water drainage was permitted in the suction-controlled tests. Only pore air drainage was permitted in the constant water content tests performed on the air-dried specimens.

Figure 9 presents the stress-strain behaviour for each suction level, in terms of deviator stress $q$ and axial strain (\%), where $q$ is equal to $\left(\sigma_{1}-\sigma_{3}\right)$, where $\sigma_{1}$ and $\sigma_{3}$ are the major and minor principal stresses. The initial and final conditions of void ratio, moisture content, dry density and degree of saturation of the triaxial specimens are presented in Table 3. Unfortunately, it is not possible to present here the evolution of the volume change during shearing, owing to a problem with the data acquisition of the volume measurements. The initial and final volumes of the

\begin{tabular}{|c|c|c|c|c|c|c|c|c|c|c|c|}
\hline \multirow{2}{*}{$\begin{array}{l}\text { Testing } \\
\text { condition }\end{array}$} & \multirow{2}{*}{$\begin{array}{c}\text { Suction: } \\
\text { kPa }\end{array}$} & \multirow{2}{*}{$\begin{array}{c}\text { Net/effective } \\
\text { confining } \\
\text { stress: kPa }\end{array}$} & \multicolumn{4}{|c|}{ Conditions after compaction } & \multicolumn{4}{|c|}{ Conditions at end of test } & \multirow{2}{*}{$\begin{array}{c}\text { Total volume } \\
\text { change during } \\
\text { test: } \%\end{array}$} \\
\hline & & & $w: \%$ & $\begin{array}{c}\rho_{\mathrm{d}}: \\
\mathrm{Mg} / \mathrm{m}^{3}\end{array}$ & $S_{r}: \%$ & e & $w: \%$ & $\begin{array}{c}\rho_{\mathrm{d}}: \\
\mathrm{Mg} / \mathrm{m}^{3}\end{array}$ & $S_{r}: \%$ & e & \\
\hline SAT & 0 & 25 & $23 \cdot 1$ & $1 \cdot 21$ & $50 \cdot 4$ & $1 \cdot 244$ & $35 \cdot 5$ & $1 \cdot 40$ & $99 \cdot 3$ & 0.940 & $14 \cdot 0$ \\
\hline SAT & 0 & 100 & $24 \cdot 0$ & $1 \cdot 19$ & $50 \cdot 6$ & $1 \cdot 290$ & $30 \cdot 9$ & $1 \cdot 51$ & $99 \cdot 5$ & 0.799 & $21 \cdot 2$ \\
\hline SAT & 0 & 300 & $23 \cdot 0$ & $1 \cdot 21$ & $49 \cdot 9$ & $1 \cdot 257$ & $27 \cdot 5$ & $1 \cdot 55$ & $99 \cdot 1$ & 0.750 & $22 \cdot 8$ \\
\hline SC & 50 & 25 & $24 \cdot 6$ & $1 \cdot 18$ & $51 \cdot 6$ & 1.296 & $27 \cdot 8$ & $1 \cdot 38$ & $74 \cdot 8$ & 0.979 & $13 \cdot 5$ \\
\hline SC & 50 & 100 & $25 \cdot 1$ & $1 \cdot 17$ & $51 \cdot 9$ & $1 \cdot 315$ & $27 \cdot 0$ & 1.49 & $88 \cdot 3$ & 0.830 & $20 \cdot 5$ \\
\hline SC & 50 & 300 & $23 \cdot 9$ & $1 \cdot 18$ & $50 \cdot 2$ & $1 \cdot 298$ & $25 \cdot 0$ & $1 \cdot 56$ & 91.9 & 0.739 & $24 \cdot 1$ \\
\hline SC & 400 & 25 & $23 \cdot 1$ & $1 \cdot 21$ & $50 \cdot 4$ & $1 \cdot 244$ & $23 \cdot 3$ & $1 \cdot 28$ & $56 \cdot 1$ & $1 \cdot 127$ & $7 \cdot 6$ \\
\hline SC & 400 & 100 & $23 \cdot 9$ & $1 \cdot 19$ & $50 \cdot 7$ & $1 \cdot 281$ & $23 \cdot 0$ & $1 \cdot 41$ & $69 \cdot 6$ & 0.932 & $15 \cdot 3$ \\
\hline SC & 400 & 300 & $23 \cdot 9$ & $1 \cdot 20$ & $51 \cdot 0$ & $1 \cdot 274$ & $22 \cdot 2$ & $1 \cdot 58$ & $84 \cdot 8$ & 0.719 & $24 \cdot 3$ \\
\hline$C W$ & $\sim 100000$ & 25 & $24 \cdot 4$ & $1 \cdot 17$ & $49 \cdot 9$ & $1 \cdot 327$ & $7 \cdot 86$ & * & * & * & * \\
\hline$C W$ & $\sim 100000$ & 100 & $24 \cdot 2$ & $1 \cdot 18$ & $50 \cdot 3$ & $1 \cdot 309$ & $6 \cdot 94$ & * & * & * & * \\
\hline $\mathrm{CW}$ & $\sim 100000$ & 300 & $24 \cdot 2$ & $1 \cdot 18$ & $50 \cdot 2$ & $1 \cdot 310$ & 8.64 & $1 \cdot 35$ & $20 \cdot 2$ & 1.011 & $13 \cdot 4$ \\
\hline
\end{tabular}

SAT, saturated; SC, suction controlled; CW, constant water content.

* Not possible to determine, as specimens largely crumbled during shearing

Table 3. Triaxial testing programme, testing conditions, initial and final specimen conditions 


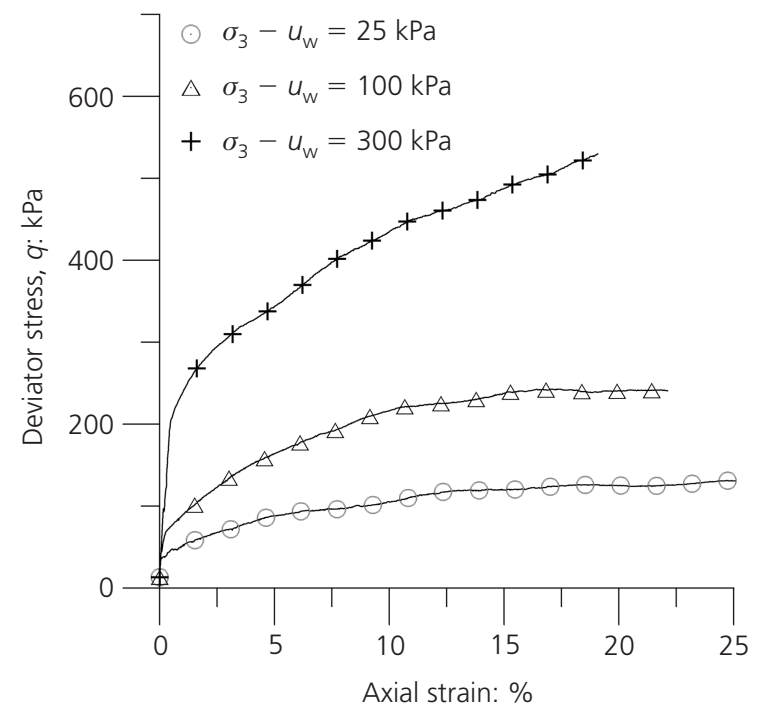

(a)

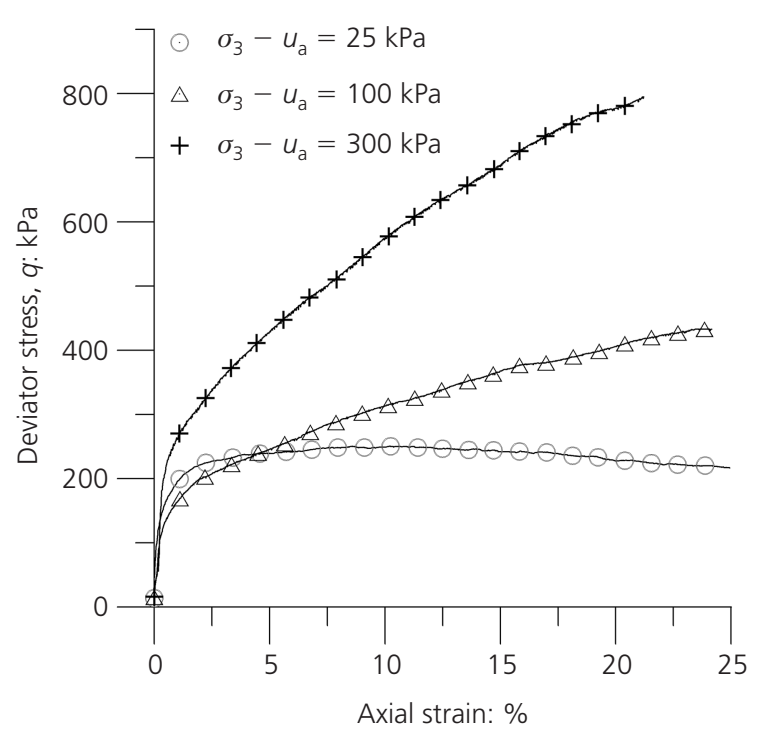

(c)

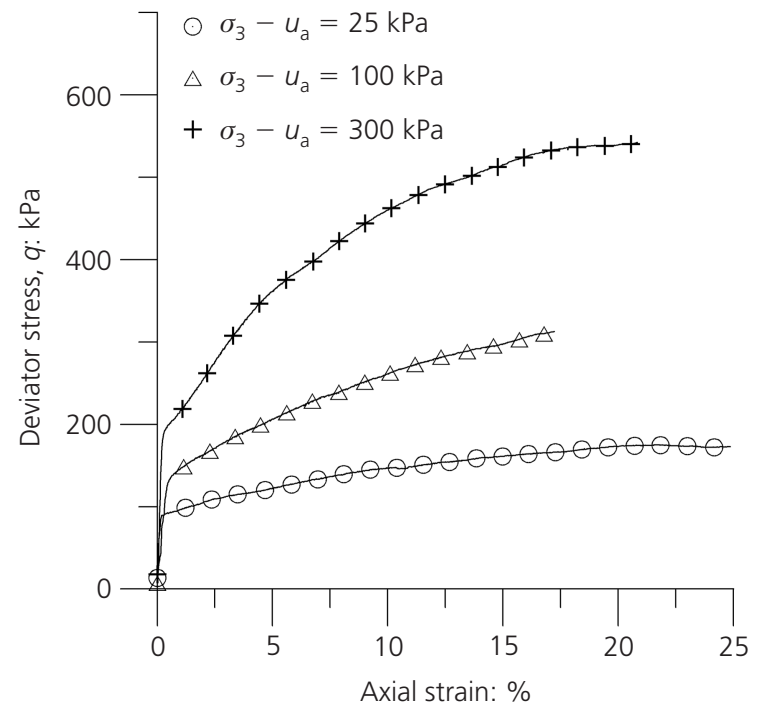

(b)

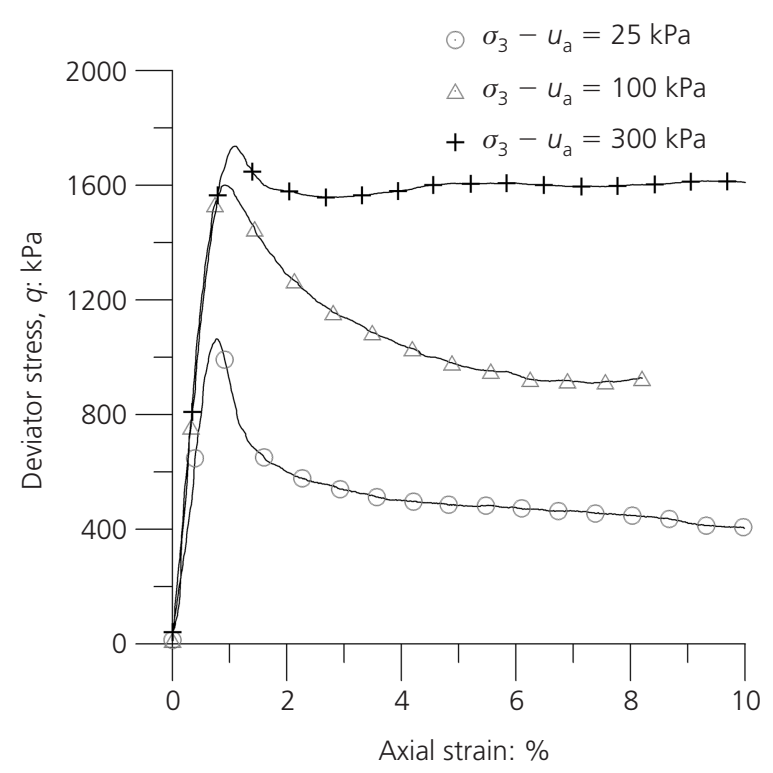

(d)

Figure 9. Deviator stress-axial strain data from triaxial compression tests: (a) saturated; (b) suction $s=50 \mathrm{kPa}$; (c) suction $s=400 \mathrm{kPa}$; (d) air dried (suction $\approx 100 \mathrm{MPa}$ )

specimens were, however, determined before and after triaxial testing, and so the overall volume change that occurred was determined. This overall volume change for each specimen is presented alongside the initial and final conditions of the triaxial specimens in Table 3.

It is evident in Figure 9 that the air-dried specimens $(s \approx 100 \mathrm{MPa}$ ) exhibit a shearing behaviour markedly different from that of the other specimens, reaching a peak deviator stress at axial strains of $0 \cdot 7-1 \cdot 1 \%$, followed by rapid softening behaviour. Distinct failure planes were evident in the two air-dried specimens at confining stresses of $25 \mathrm{kPa}$ and $100 \mathrm{kPa}$. Failure planes and barrelling were observed in the air-dried specimen at $300 \mathrm{kPa}$ confining stress at the end of the test. Aside from the airdried specimens, and with the exception of the specimen tested at a net confining stress of $25 \mathrm{kPa}$ and suction of $400 \mathrm{kPa}$, all the other specimens exhibited strain-hardening behaviour, with many appearing not to reach their peak deviator stress even at axial 
strains between $20 \%$ and $25 \%$. Evidence of barrelling was observed in all these specimens; consequently, changes in the cross-sectional area due to barrelling during shearing were taken into account when calculating the deviator stress.

Figure 10 compares the stress-strain behaviour ( $q$ against axial strain) for specimens tested under different suction levels at the same net confining stress. It is evident that, as suction increases, the peak or residual deviator stress reached increases. The peak shear stress reached, and the stress path followed during the triaxial tests, are presented in Figure 11 in $q-p$ space, where $p$ is the mean net stress, equal to the excess of mean stress $\sigma_{\mathrm{m}}$ over air pressure $u_{\mathrm{a}}$, where $\sigma_{\mathrm{m}}$ is equal to $\left(\sigma_{1}+2 \sigma_{3}\right) / 3$ for cylindrical triaxial specimens.

One of the most commonly used shear strength criteria in unsaturated soils is that proposed by Fredlund et al. (1978)

1. $\tau=c^{\prime}+\left(\sigma-u_{\mathrm{a}}\right) \tan \phi^{\prime}+\left(u_{\mathrm{a}}-u_{\mathrm{w}}\right) \tan \phi^{\mathrm{b}}$

where $\tau$ is the shear strength of unsaturated soil, $c^{\prime}$ is the apparent cohesion, $\phi^{\prime}$ is the effective angle of friction, $\sigma-u_{\mathrm{a}}$ is the net normal stress and $\phi^{\mathrm{b}}$ is the shear strength contribution due to matric suction. Initially it was proposed that the increase in shear strength due to an increase in suction was linear (e.g. Fredlund et al., 1978). However, experiments conducted over larger suction ranges indicated that the relationship was nonlinear, with $\phi^{\mathrm{b}}$ decreasing with increasing suction towards a constant value (e.g. Escario and Juca, 1989; Escario and Saez, 1986).

In order to investigate the influence of suction on the shear strength behaviour of the Bengawan Solo fill, the parameters $\phi^{\prime}$ (effective angle of friction) and $c^{\prime}$ (apparent cohesion) were determined from Mohr's circles, and are plotted in Figure 12 against a $\log$ scale of suction plus atmospheric pressure. The effective stress parameters were interpreted by taking the failure envelope corresponding to the best fit to the three Mohr's circles drawn for each suction level. In Figure 12a it appears that $\phi^{\prime}$ increases with increasing suction. However, the shear strength criterion in Equation 1 assumes that $\phi^{\prime}$ does not vary with suction. Similar evidence for $\phi^{\prime}$ increasing with suction has reported by several authors (e.g. Futai and Almeida, 2005; Toll, 2000). Delage and Graham (1996) collated various experimental datasets and found evidence of angles of friction both increasing and decreasing with increasing suction. For each of these datasets, cohesion increased with increasing suction. Figure $12 \mathrm{~b}$ presents the variation in apparent cohesion with suction for the Bengawan Solo fill; cohesion appears to be less influenced by suction, at least within the lower suction range $(0-400 \mathrm{kPa})$. The high apparent cohesion determined for the air-dried specimens $(260 \mathrm{kPa})$ may be explained by the highly aggregated specimen created by air-drying. It is noted, however, that the trends presented in Figures $12 \mathrm{a}$ and $12 \mathrm{~b}$ are heavily

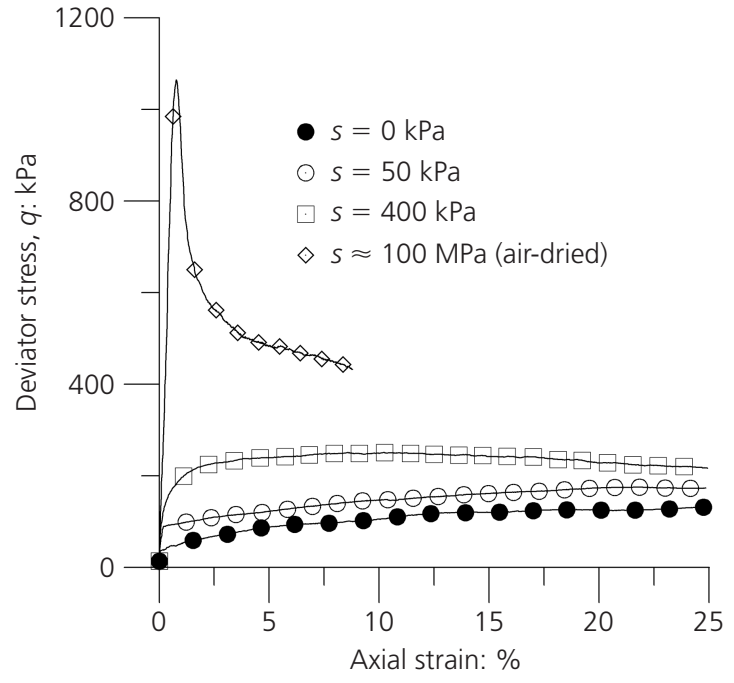

(a)

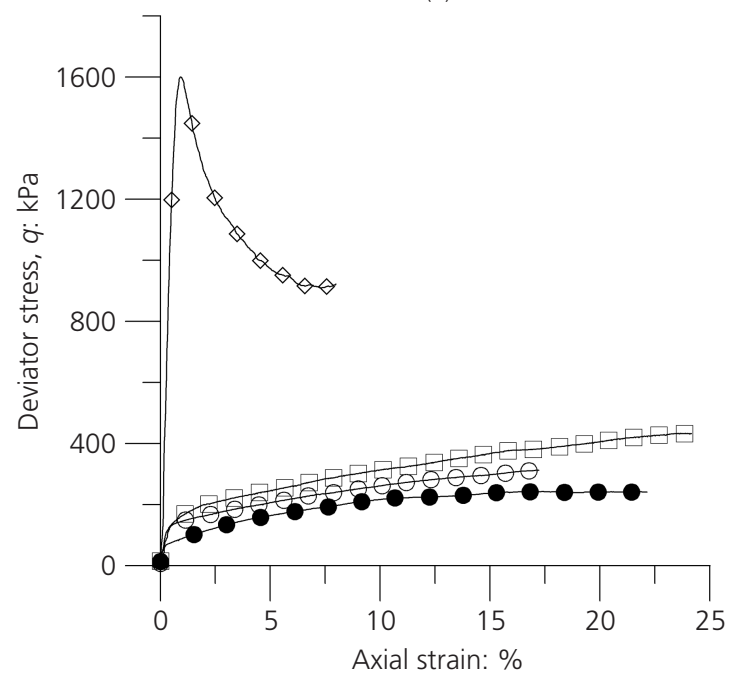

(b)

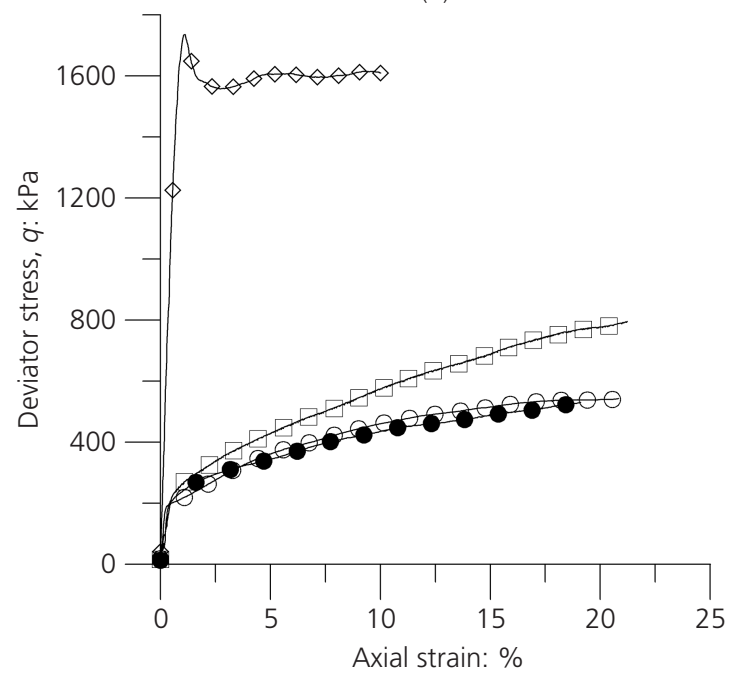

(c)

Figure 10. Deviator stress-axial strain data from triaxial compression tests at different net confining stresses: (a) $25 \mathrm{kPa}$; (b) $100 \mathrm{kPa}$; (c) $300 \mathrm{kPa}$ 


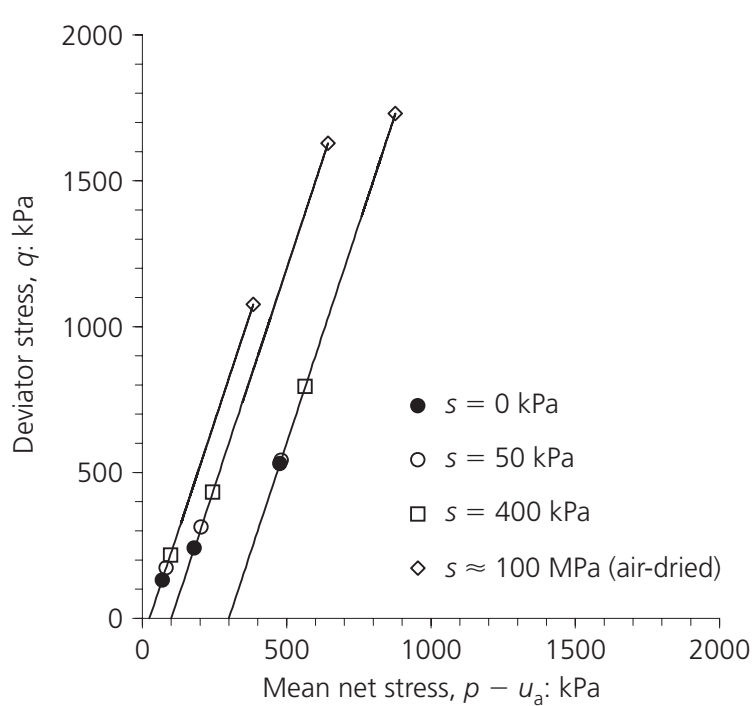

Figure 11. Peak deviator stresses and stress path followed during triaxial tests in $q-p$ space

influenced by the effective shear strength parameters selected for the air-dried specimens. For this reason, it is recommended that further testing be carried out at intermediate suction levels, between $400 \mathrm{kPa}$ and $100 \mathrm{MPa}$. Further tests should also be carried out at additional stress levels to compensate for variation within the data at each suction level.

\section{Discussion}

A routine slope stability analysis was carried out using the limit equilibrium method using Slope/w (Geoslope International Ltd) in order to investigate whether the variation in shear strength with suction may influence embankment stability. The factor of safety was computed using the Morgenstern-Price method (Morgenstern and Price, 1965) and a half-sine inter-slice function. Two scenarios were investigated, representing: (a) the condition of the embankment immediately after construction, in which the embankment fill is unsaturated and the river level is low, as construction was carried out during the dry season; and (b) the condition of the embankment typical of the wet season, when most of the embankment body has become saturated and the river level is high. In scenario (a) the river level was assumed to be $1 \mathrm{~m}$ high; in scenario (b) the river level was set to be $7 \mathrm{~m}$ high (Figure 2). Of course, there are many other potential scenarios that could be investigated, but here the aim was to investigate the embankment stability under these two extreme conditions. For the saturated fill material (below the water table), the saturated parameters determined in the triaxial tests were used: $\phi^{\prime}=24.9^{\circ}$ and $c^{\prime}=30 \mathrm{kPa}$. The unsaturated material (above the water table) was assumed to be at a moisture content of approximately 22$23 \%$ at a suction of $400 \mathrm{kPa}$, corresponding to dry of optimum compaction conditions. Values of $\phi^{\prime}=31.4^{\circ}$ and $c^{\prime}=50 \mathrm{kPa}$ determined at this suction level in the triaxial tests were used.

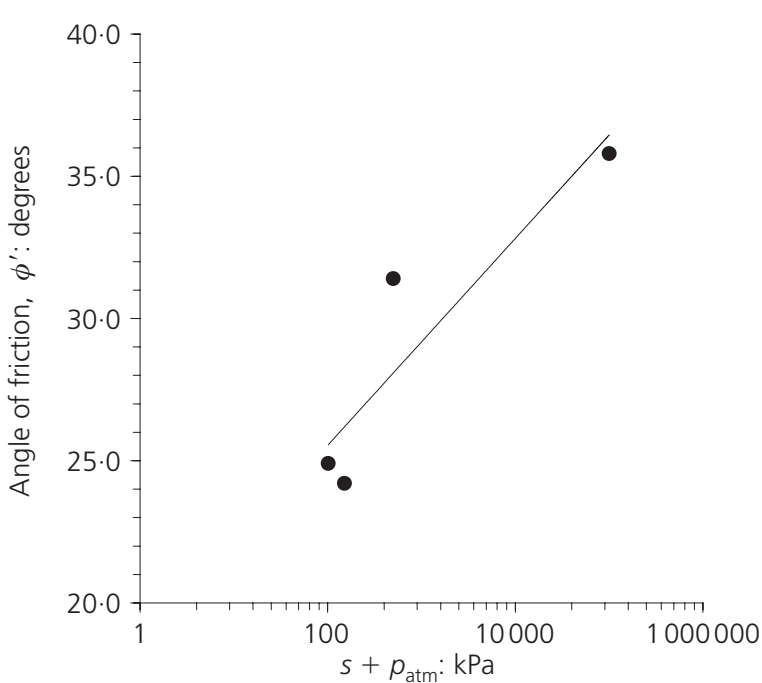

(a)

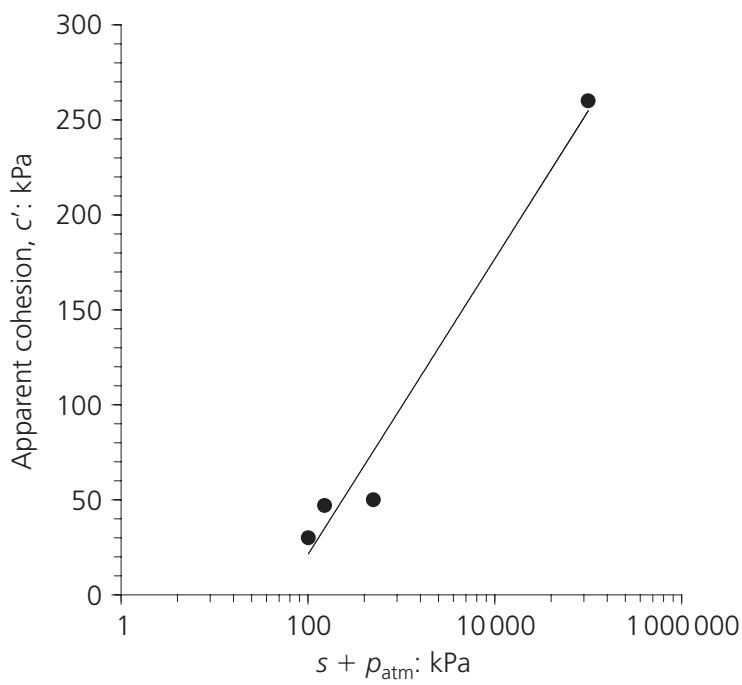

(b)

Figure 12. Variation in shear strength parameters against suction + atmospheric pressure: (a) effective angle of friction, $\phi^{\prime}$;

(b) apparent cohesion, $c^{\prime}$

Considering that evaporation considerably exceeds precipitation in the Bojonegoro area during the dry season (Takeuchi et al., 1995), it is not unreasonable to assume that such moisture contents may be typical of the fill material during the dry season.

The borehole data presented in Figure 5a were used in the selection of the geotechnical properties for the founding layers, assuming $C_{\mathrm{u}}=5 \mathrm{~N}$, after Stroud and Butler (1975). The founding layers were assumed to be fully saturated at all times, and were considered to be undrained. Although this may not strictly be the case, these assumptions were considered suitable to investigate the influence of suction on the embankment stability. Additionally, the influence of loading due to the gabions present along this section of embankment was also introduced into the stability 
analysis. The gabion fill was assumed to have a density of $1.6 \mathrm{Mg} / \mathrm{m}^{3}$ (MGS, 2004).

Considering only the increase in water level between the dry (scenario (a)) and wet season (scenario (b)), and thus changes in the bulk unit weight and shear strength of the fill material due to saturation, the factor of safety determined was higher in the wet season $(2 \cdot 19)$ than in the dry season $(1 \cdot 52)$. The higher factor of safety determined for the wet season scenario may be explained by considering that the higher river level applies a greater hydrostatic pressure, which acts to stabilise the embankment. This simple analysis indicates that the variation of the shear strength of the fill material due to changes in suction is not the mechanism responsible for the global failure of the embankment illustrated in Figure 3. It should be noted that cracks due to desiccation were not included in the dry season stability analysis, and may contribute to a lower factor of safety during the dry season. Furthermore, in the wet season the high river level contributed to stabilisation of the embankment against outward slip failures; however, the stability of the landward side would be reduced owing to saturation of the fill. The stability of the landward side was not investigated here, as typically along this stretch of river the crest of the embankment is only several metres above the natural ground level on the landward side (at the gabion-reinforced section of embankment this height is approximately $3 \mathrm{~m}$ ), and landward slip failures were not observed during the site investigation.

A simple undrained analysis was carried out to investigate the effect of rapid drawdown on the embankment stability, and a low factor of safety of 1.12 was obtained. However, the failure of the gabion-reinforced embankment in Figure 3 was not linked with any closure of the Babat barrage upstream. The value does, however, indicate that embankments constructed with the Bengawan Solo fill material may be susceptible to instability due to rapid drawdown, as has been observed along the embankments (Soemitro, private communication, 2006). Durations of prolonged and heavy rainfall in the Bengawan Solo Basin can give rise to peak discharges of around $2500 \mathrm{~m}^{3} / \mathrm{s}$ (Hidayat et al., 2008; Takeuchi et al., 1995). Such peak discharges may be maintained for several days, and also fall rapidly in a matter of days; correspondingly, river levels may also vary significantly in short time periods (Takeuchi et al., 1995). If we consider that volumetric collapse compression may have occurred during saturation, then, as the river level reduces after storm events, even poorer drainage conditions may exist in the fill body, potentially triggering rapid drawdown failures. Further detailed information on the slope stability analyses presented herein can be found in El Mountassir (2011).

It is likely, then, that the global failure of the gabion-reinforced embankment was due to a combination of different factors, including seepage, overtopping, erosion and the volumetric collapse of poorly compacted layers. However, investigation of the influence of such factors would require coupled seepage analyses and unsaturated finite-element modelling of the embankments, which are outside the scope of this paper. It is suggested here that compacting the fill material to a higher dry density (e.g. 90-95\% Proctor density) could potentially reduce the susceptibility of the Bengawan Solo fill to volumetric collapse behaviour, and minimise the erodibility of this material.

\section{Conclusions}

This paper has presented a comprehensive characterisation of the Bengawan Solo fill material, including its compaction and soil water retention behaviour. A conventional load and soak oedometer test identified that this material may undergo significant volumetric collapse when wetted under constant load. The shear strength of this fill material was investigated under four different suction levels and three different net confining stresses. Suction appeared to influence the effective angle of friction more strongly than cohesion. A routine slope stability analysis indicated that the reduction in shear strength due to saturation did not negatively influence the stability of the Bengawan Solo embankment. It is likely that a combination of other mechanisms has been responsible for the global failure of the gabion-reinforced embankment presented in Figure 3. The low dry densities found during the site investigation, and the additional loading due to the remediation works, appear to provide conditions favouring volumetric collapse. The collapsible behaviour and susceptibility to erosion of this fill material should be investigated in further detail, in order to determine whether such mechanisms may play a relevant role in triggering such a failure, and to investigate the dependence of these processes on the dry density achieved during compaction.

In summary, this paper has illustrated that saturation may contribute to volumetric collapse compression and the loss of strength of fill materials, particularly in the case of poorly compacted fills, as at the Bengawan Solo site. Furthermore, it is apparent that these deterioration processes, alongside the mechanism of rapid drawdown, may be responsible for triggering failures in flood defences.

\section{Acknowledgements}

The authors would like to thank Dr Ana María Fernández Díaz from the CIEMAT Laboratory, Madrid, Spain, for carrying out the X-ray diffraction investigation. The support of Professor Mark Dyer during the initial stages of this research is also appreciated. The authors would also like to thank Dr Minna Karstunen for her assistance in the preparation of this paper for submission. The authors gratefully acknowledge the support of the Carnegie Trust, Bellahouston Travelling Scholarship, the Research Enhancement Group at the University of Strathclyde and the EC (contract number MIF1-CT-2006-040375).

\section{REFERENCES}

Atique A, Sánchez M and Romero E (2009) Investigation of crack desiccation in soil from a flood protection embankment. 
In Unsaturated Soils: Experimental Studies in Unsaturated Soils and Expansive Soils, Proceedings of the 4th Asia-Pacific Conference on Unsaturated Soils, Newcastle, Australia (Sheng D, Buzzi O and Fityus S (eds)). Taylor \& Francis, London, vol. 1, pp. 51-56.

Basham DL, Blanton WR Jr, Dorman J, Garcia DF, Gilson S, Halpin E, Harder LF Jr, Jacoby KM, Kennedy C, Matsuda E, Mayer RG, Perri P IV, Medlock SR, Sanders CA, Spagna S, Stankiewicz MR, Stockton SL, Sweeney J, Thomas M, Turner RA Jr, Verigin SW Williams WD and Zien TR (2009) Draft: Recommendations for a National Levee Safety Program: A Report to Congress from the National Committee on Levee Safety, 15 January 2009.

Baudin CMH, Moes CJB and van Baalen M (1989) The influence of uplift water pressures on the deformations and stability of flood embankment. Proceedings of the 12th International Conference on Soil Mechanics and Foundation Engineering, Rio de Janeiro 3, 1713-1716.

Bezuijen A, Kruse GAM and Van MA (2005) Failure of peat dikes in the Netherlands. Proceedings of the 16th International Conference on Soil Mechanics and Geotechnical Engineering, Osaka, vol. 3, 1857-1860.

Brown RL (1999) Vientiane Plain flood protection: urgent phase. Flood Management and Mitigation in the Mekong River Basin (Technical Session IV Flood Control Works). Food and Agriculture Organization of the United Nations, Regional Office for Asia and the Pacific, Bangkok, Thailand, RAP Publication 1999/14, pp. 171-180.

BSI (British Standards Institution) (1986) BS 8004: Code of Practice for Foundations. British Standards Institution, Milton Keynes.

BSI (1990a) BS 1377-9: Methods of Test for Soils for Civil Engineering Purposes. Part 9: In Situ Tests. British Standards Institution, Milton Keynes.

BSI (1990b) BS1377-4: Methods of Test for Soils for Civil Engineering Purposes: Part 4: Compaction-Related Tests. British Standards Institution, Milton Keynes.

BSI (1999) BS 5390: Code of Practice for Site Investigations. British Standards Institution, Milton Keynes.

Bulut R, Lytton RL and Wray WK (2001) Soil suction measurements by filter paper. In Expansive Clay Soils and Vegetative Influence on Shallow Foundations (Vipulanandan C, Addison M B and Hasen M (eds)). ASCE Geotechnical Special Publication No. 115, ASCE, Reston, VA, pp. 243261.

Cooling L and Marsland A (1954) Soil mechanics studies of failures in the sea defence banks of Essex and Kent. Proceedings of the Conference on the North Sea Floods of 31st January/1st February, 1953. Institution of Civil Engineers, London, pp. 58-73.

Dapporto S, Rinaldi M and Casagli N (2001) Failure mechanisms and pore water pressure conditions: analysis of a riverbank along the Arno River (central Italy). Engineering Geology 61(4): 221-242.

Dapporto S, Rinaldi M, Casagli N and Vannocci P (2003)
Mechanisms of riverbank failure along the Arno River, central Italy. Earth Surface Processes and Landforms 28(12): $1303-1323$.

Defra (Department for Environment, Food and Rural Affairs) (2008) The Government's Response to Sir Michael Pitt's Review of the Summer 2007 Floods. Department for Environment, Food and Rural Affairs, London.

Delage P and Graham J (1996) Mechanical behaviour of unsaturated soils. Proceedings of the 1st International Conference on Unsaturated Soils, Paris, 1223-1256.

Delage P, Romero E and Tarantino A (2008) Recent developments in the techniques of controlling and measuring suction. Proceedings of the 1st European Conference on Unsaturated Soils, Durham, 33-52.

Dunbar JB, Torrey VH III and Wakeley LD (1999) A Case History of Embankment Failure: Geological and Geotechnical Aspects of the Celotex Levee Failure, New Orleans, Louisiana. Technical report GL-99-11, prepared for US Army Engineer Division, Mississippi Valley and US Army Corps of Engineers Civil Works Research and Development Program, Risk Analyses for Dam Safety.

Dyer M (2004) Performance of flood embankments in England and Wales. Proceedings of the Institution of Civil Engineers Water Management 157(4): 177-186.

Dyer M, Utili S and Zielinski M (2009) Field survey of desiccation fissuring of flood embankments. Proceedings of the Institution of Civil Engineers - Water Management 162(3): 221-232.

El Mountassir G (2011) Behaviour of a Collapsible Structured Unsaturated Fill Material. PhD thesis, University of Strathclyde, Glasgow, UK.

Escario V and Juca F (1989) Strength and deformation of partly saturated soils. Proceedings of the 12th International Conference on Soil Mechanics and Foundation Engineering, Rio de Janeiro 1, 43-46.

Escario V and Saez J (1986) The shear strength of partly saturated soils. Géotechnique 36(3): 453-456.

FAO RAP (Food and Agriculture Organization of the United Nations Regional Office for Asia and the Pacific) (1999) Summary report. Flood Management and Mitigation in the Mekong River Basin. FAO RAP, Bangkok, Thailand, RAP Publication 1999/14, pp. 1-189.

Fookes PG (1990) Tropical residual soils. Report of the Geological Society Engineering Group working party. Quarterly Journal of Engineering Geology 23(1): 4-101.

Fredlund DG, Morgenstern NR and Widger RA (1978) The shear strength of unsaturated soils. Canadian Geotechnical Journal 15(3): 313-321.

Futai MM and Almeida MSS (2005) An experimental investigation of the mechanical behaviour of an unsaturated gneiss residual soil. Géotechnique 55(3): 201-213.

Ghataora GS, Burns B, Hassan M and Morris M (2007) Soil Piping Tests on Thorngumbald Flood Embankment. Joint Defra/EA Flood and Coastal Erosion Risk Management R\&D 
Programme, Science Report FD2411/TR3.

Hidayat F, Sungguh HM and Harianto (2008) Impact of climate change on floods in Bengawan Solo and Brantas river basins, Indonesia. Proceedings of the 11th International Riversymposium, Brisbane. Published online at www.riversymposium.com.

Hilf JW (1956) An Investigation of Pore Water Pressure in Compacted Cohesive Soils. PhD thesis, US Bureau of Reclamation.

Hird CC, Marsland S and Schofield AN (1978) The development of centrifuge models to study the influence of uplift pressures on stability of a flood bank. Géotechnique 28(1): 85-106.

Hoffmann C and Tarantino A (2008) Loading-collapse tests for investigating compressibility and potential collapsibility of embankment coarse well graded material. Proceedings of the 1st European Conference on Unsaturated Soils, Durham, 967-972.

Jakarta Post (2009) Bojonegoro levee section collapses, affected residents flee. The Jakarta Post, 28 February. See http:// www.thejakartapost.com/news/2009/02/28/bojonegoro-leveesection-collapses-affected-residents-flee.html (accessed 03/03/2011).

Jennings JEB and Knight K (1957) The additional settlement of foundations due to collapse of structure of sandy subsoil on wetting. Proceedings of the 4th International Conference on Soil Mechanics and Foundation Engineering, London 1, 316319.

Leroueil S, Magnan J-P and Tavenas F (1990) Embankments on Soft Clay. Ellis Horwood, London.

Lindenberg J and de Groot M (1998) Overall geotechnical stability investigation. In Dikes and Revetments: Design, Maintenance and Safety Assessment (Pilarczyk K (ed.)). Balkema, Rotterdam, pp. 429-440.

Marsland A (1957) The design and construction of earthen flood banks. Journal of the Institution of Water Engineers 11(3): 236-258.

Marsland A (1961) A study of a breach in an earthen embankment caused by uplift pressures. Proceedings of the 5th International Conference on Soil Mechanics and Foundation Engineering, Paris 2, 663-668.

Marsland A (1968) The Shrinkage and Fissuring of Clay in Flood Banks. Building Research Station, Garston, Internal Report No. $39 / 68$.

Marsland A and Randolph M (1978) A study of the variations and effects of pore water pressures in the pervious strata at Crayford marshes. Géotechnique 28(4): 435-464.

Miller SP and Ralston DC (1987) Embankment overtopping - case histories. In Hydraulic Engineering, Proceedings of the 1987 National Conference on Hydraulic Engineering, August 3-7, 1987, Williamsburg, Virginia (Ragan RM (ed.)). ASCE, New York, pp. 739-744.

MGS (Modular Gabion Systems) (2004) Gabion Walls Design Guide. MGS, Mobile, AL, USA, Revision 11/04.

Möller J, Weißmann R, Schüttrummpf H, Grüne J, Oumeraci H, Richwien W and Kudella M (2002) Interaction of wave overtopping and clay properties for seadikes. Proceedings of the 28th International Conference on Coastal Engineering, Cardiff 2, 2105-2115.

Morgenstern NR and Price VE (1965) The analysis of the stability of general slip surfaces. Géotechnique 15(1): 79-93.

Morris M, Dyer M and Smith P (2007) Management of Flood Embankments: A Good Practice Review. Defra, London, R\&D Technical Report FD2411/TR1.

Nam S, Gutierrez M, Diplas P, Petrie J, Wayllace A, Lu N and Muñoz JJ (2009) Comparison of testing techniques and models for establishing the SWCC of riverbank soils. Engineering Geology 110(1-2): 1-10.

Nuth M and Laloui L (2008) Advances in modelling hysteretic water retention curve in deformable soils. Computers and Geotechnics 35(6): 835-844.

Padfield C and Schofield A (1983) Development of centrifugal models to study the influence of uplift pressures on stability of a flood bank. Géotechnique 33(4): 57-66.

Perry EB (1998) Innovative Methods for Levee Rehabilitation. US Army Corps of Engineers, Technical Report REMR-GT-26.

Pinyol NM, Alonso EE and Olivella S (2008) Rapid drawdown in slopes and embankments. Water Resources Research 44(4): $1-5$.

Rinaldi M, Casagli N, Dapporto S and Gargini A (2004) Monitoring and modelling of pore water pressure changes and riverbank stability during flow events. Earth Surface Processes and Landforms 29(2): 237-254.

Sentenac P and Zielinski M (2009) Clay fine fissuring monitoring using miniature geo-electrical resistivity arrays. Environmental Earth Sciences 59(1): 205-214.

Simon A, Langendoen EJ, Collison A and Layzell A (2003) Incorporating bank-toe erosion by hydraulic shear into a bankstability model: Missouri river, Eastern Montana. Proceedings of the EWRI-ASCE World Water and Environmental Resources Congress, Philadelphia, PA, pp. 70-76.

Simon A, Thomas RE., Curini A and Shields Jr FD (2002) Case study: Channel stability of the Missouri river, Eastern Montana. Journal of Hydraulic Engineering, ASCE 28(10): 880-890.

Soemitro RAA (2005) Performance and Reliability Evaluation Research. Case Study: River Solo. Report to East Java, Ministry of Public Works, Institut Teknologi Sepuluh Nopember (in Indonesian).

Stroud MA and Butler FG (1975) The standard penetration test and the engineering properties of glacial materials. Proceedings of the Symposium on Engineering Behaviour of Glacial Materials, Birmingham, pp. 124-135.

Sudarsono (2009) The Bengawan Solo Water Council: Providing Insight and Directions. Centre for River Basin Organizations and Management, Solo, Central Java, Indonesia, CRBOM Small Publications Series No. 5. See http://crbom.org/SPS/ Docs/SPS05-TKPSDA-0.pdf (accessed 03/03/2011).

Takeuchi K, Jayawardena AW and Takahasi Y (1995) Catalogue of Rivers for Southeast Asia and the Pacific: Volume 1. UNESCO-IHP Regional Steering Committee for Southeast Asia and the Pacific, Jakarta, Indonesia. 
Toll DG (2000) The influence of fabric on the shear behaviour of unsaturated compacted soils. In Advances in Unsaturated Geotechnics (Shackleford C, Houston S L and Chang N-Y (eds)). ASCE, Reston, VA, ASCE Geotechnical Special Publication No. 99, pp. 222-234.

Van M, Koelewijn A and Barends F (2005) Uplift phenomenon: model, validation, and design. International Journal of
Geomechanics, ASCE 5(2): 98-106.

Ward WH (1948) A slip in a flood defence bank constructed on a peat bog. Proceedings of the 2nd International Conference Soil Mechanics and Foundation Engineering, Rotterdam 2, 19-23.

Ward WH, Penman A and Gibson RE (1955) Stability of a bank on a thin peat layer. Géotechnique 5(2): 154-163.
WHAT DO YOU THINK?

To discuss this paper, please email up to 500 words to the editor at journals@ice.org.uk. Your contribution will be forwarded to the author(s) for a reply and, if considered appropriate by the editorial panel, will be published as a discussion in a future issue of the journal.

Proceedings journals rely entirely on contributions sent in by civil engineering professionals, academics and students. Papers should be $2000-5000$ words long (briefing papers should be 1000-2000 words long), with adequate illustrations and references. You can submit your paper online via www.icevirtuallibrary.com/content/journals, where you will also find detailed author guidelines. 